\title{
Providing Suitable Formal \& Economic Shelter Opportunities to Curb the Growth of Informal settlements
}

\author{
Sherif Helmy Ahmed \\ Lecturer, Department of Architectural Engineering, High Institute of Engineering-15 May \\ Cairo, Egypt. \\ sh_100sh@yahoo.com
}

(Received 30/6/2020; accepted for publication 15/10/2020.)

\begin{abstract}
Informal settlements are considered one of the most important urban development problems in Cairo. It is difficult to control the growth of informal settlements by regulations and laws only, but through understanding the requirements of marginalized groups and their motives for resorting to building in this random pattern. The study sheds light on the problem of the growth of these areas. It aims to develop a thesis that achieves a balance between the needs of people with limited income from adequate housing on one hand, and the minimum requirements for an adequate urban and healthy environment on the other. The study concluded that an officially approved and economic shelter can be provided that commensurate with the actual needs of these groups. This can be achieved through the idea of taking advantage of the right to share in residential and service courts as a tool to achieve the requirements of building regulations, while minimizing losses in the built up land area. In this context, an opportunity is provided for an economical alternative that is compatible with building regulations, within official urban areas; hence, there will be no need to build in contravention of building regulations. This reduces the growth of existing informal settlements and the emergence of new ones.
\end{abstract}

Keywords: Informal settlements, Slums, Ashwa'iyyat, Building regulations, Easement right, Urban fabric.

\section{Introduction}

Shelter is considered as one of the most important requirements of a decent human life, which cannot be summed up in a residential unit only. It is an integrated lifestyle in an integrated urban environment. Thus the search for a better and safer life, with job opportunities and life services was the main motive for many categories of Egyptian people to emigrate from the rural areas to the cities. Cairo has represented a strong attraction due to the unremitting and rapid growth of the industrial base in its suburbs since the sixties of the last century, and the availability of various job opportunities, which caused its rapid population growth.

This population growth led to the need for shelter at the lowest possible cost. Thus, the problem of low-income classes grew, and was the most important factor in the emergence of informal settlements. This is in addition to the weak role of supervisory agencies and the inability of the state to provide alternative solutions, such as building residential units or providing land plots for this class. Rather, the regulations were not compatible to the socio-economic conditions of low-income people.

The State has not developed innovative controls and solutions that maintain the balance between achieving a healthy and social environment for residential communities on one hand, and the limited economic capacity of population groups on the other, who have automatically moved to meet their needs by building informal settlements that don't abide by any planning restrictions and far from the state's supervision. 


\subsection{Research Goal}

The research aims to find a way to provide appropriate formal and economic shelter opportunities, to meet the actual needs of low-income groups. This can be achieved through the possibility of taking advantage of the right of the participant in the courts, as a means to provide suitable urban environment, within the economic limits available to that category. This curbs the formation of more informal settlements, or the growth of existing areas with the same unplanned approach.

\subsection{Research Methodology}

In this context, the right of marginalized social groups in a shelter at the lowest cost and with the simplest procedures without prejudice to public health requirements must be taken into account. To achieve the charter of the United Nations that affirms the right of housing in article 25: "Everyone has the right to a standard of living, adequate for the health and safety of himself and of his family" (GIZ 2011).

The research approach is based on the formulation of a methodology through which the research objectives can be achieved at four levels:

- First: A review of the problem of informal settlements and a summary of the requirements governing buildings in Egypt.

- Second: To identify the current situation through Dar El Salaam case study as an example.

- Third: The social housing offers in the new Cairo as a non-traditional reference to activate participation in service courts.

- Fourth: Provide a flexible vision to modify the regulations and implement their role in improving the urban environment of the informal settlements within the available economic and cultural potential of the low-income population in these areas.

\section{A Review of Informal Settlements and Buildings Regulations}

\subsection{The Problem of Informal Settlements}

The phenomenon of informal settlements began in Egypt after t World War II. However, it worsened significantly in the 1960 s and increased by $4.4 \%$ in the period from 1960 to 1966 in Greater Cairo. This period is the beginning of the increase in the phenomenon of informal settlements, especially on agricultural lands. The growth concentrated in central cities especially Cairo, as it's the capital, both administrative and economic, with the concentration of industrial activities. This increased the rate of rural migration, and thus the informal settlements in Greater Cairo were established on the agricultural areas around the Nile Basin. (Regina 2009)

Despite the increase and spread of informal settlements, the government authorities ignored the problem due to the State's limited capacity to solve the deficit in low-income housing. The State's intervention was issuing the Republican Decree No. (29) for the year 1966 to recognize the illegal division of lands and obligate the owners to introduce facilities (ElBatrawy 2009). This law did not affect the growth of informal settlements, so the state adopted governmental (social) housing programs for low-income people, that places full responsibility on the State, but it proved to be ineffective (Ragih 2008) and this is due to:

- Failure to meet the new housing needs of the population and the high indirect cost of these projects in terms of providing transportation for residents from the new cities to their workplaces, and their connection with the rest of the regions.

- The deterioration of the state of government housing projects, due to lack of maintenance.

Estimates of the number of informal settlements differ from one source to another, and this discrepancy is due to the lack of a sound method of counting. However, it can be mentioned that in 2007, the Ministry of Local Development estimated the presence of 1171 informal settlements in Egypt with a population of 15 million, $40 \%$ of whom live in Greater Cairo. This confirms the fact that it is not an exceptional phenomenon or a sub-issue in Egypt (GIZ, 2011). Also the annual report of the United Nations Population Fund for the year 2008 indicates that more than 15.5 million Egyptian citizens live in informal settlements, which is approximately $20 \%$ of the total population of the republic. Where there are 81 informal settlements inhabited by about 8 million people, 68 of which are undergoing improvement and 13 areas that need to be removed (25)(Information and Decision SupportCenter 2014). 


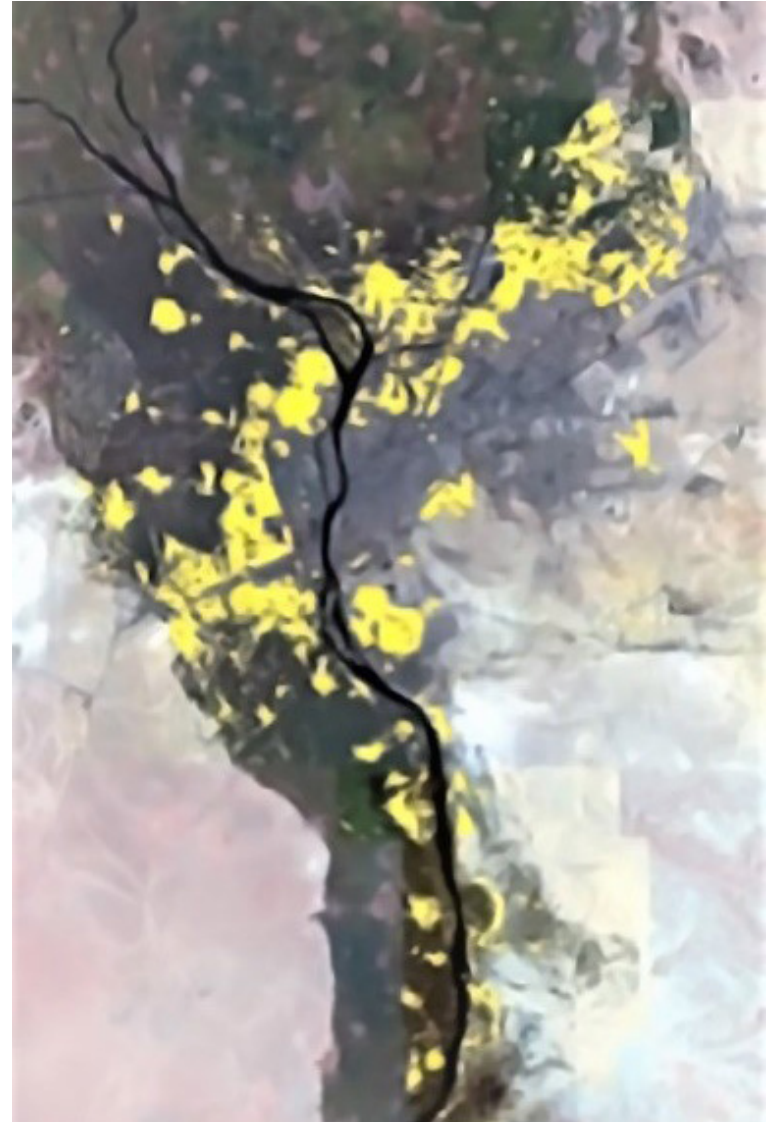

Figure 1. Informal settlements distribution (GIZ 2011).

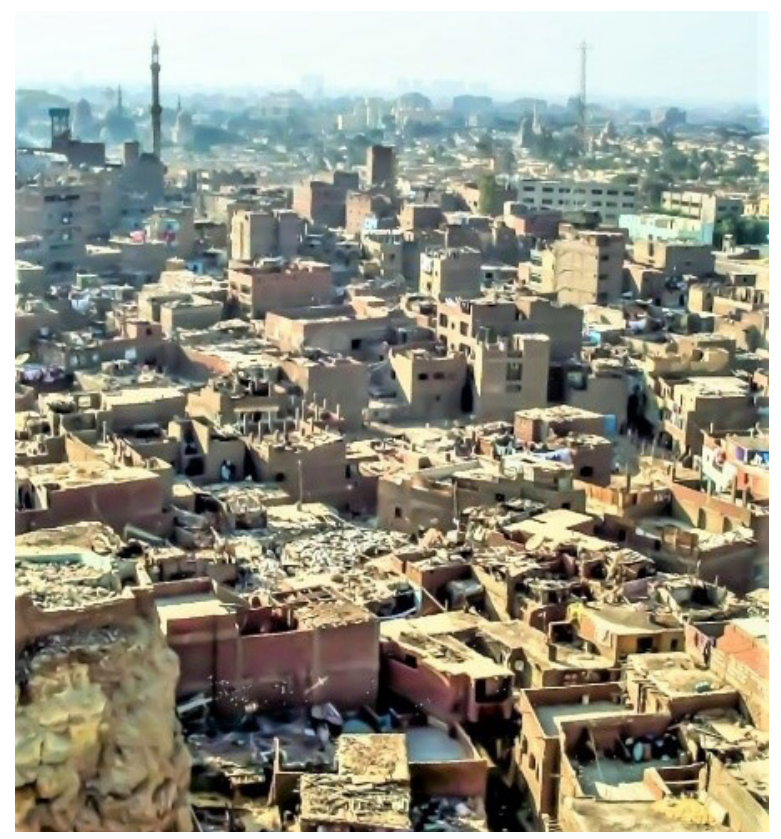

Figure 2. Informal settlements . (Sims 2003).
Informal settlements are concentrated in 20 neighborhoods within Cairo governorate (Ain Shams - West Nasr City - East Nasr City - AlMarg - Al-Matareya - El-Salam - Manshaet Nasser - Al-Waili - Al-Sahel - Shubra - Al Zaytoun - Hadayek Al-Qobba - Al-Sharabia. - Dar ElSalam and Al Basateen - Al Tebeen - Al Sayeda Zeinab - Old Cairo- Helwan) (Information and Decision Support Center 2014). Fig 1, Fig 2

\subsubsection{Informal Settlements Definition}

The word "Ashwa'iyyat" is the term used in Egypt to express informal settlements, which can be defined in a simplified way: "It is all that was created by self-effort, whether one or more buildings especially in degraded areas. As a result of the weakness of the role of supervisory agencies and urban planning, they are built on land not intended for construction as outlined in the cities' master plans. The state of the buildings may be good, but can be environmentally or socially unsafe and lack basic services and facilities". (Center, 2014).

\subsubsection{Informal settlements classification}

The classification of informal settlements varies according some elements, as origin, age, location, size and boundaries, compliance with requirements, source of threat, construction and urban mass. (H. N. M. 2015). All of these rankings are detailed. But in the research we rely on dividing them according to Law No. 119 of 2008 which states that (Cairo Governorate 2008):

Unplanned areas that haven't been developed according to detailed plans or subdivision plans and aren't subject to planning and construction requirements. They are mostly buildings that are structurally acceptable and built on privately owned agricultural land and were provided with facilities later on.

Areas, whose uses are unsuitable for their distinct location and include degraded areas, and parts of the cemeteries, which they used for housing, some of which are unsafe areas. Also they classified according to the nature of the lands established by the urban pattern as follows: (I. 2004).

- The areas that were created and were desert, built according to topography, and characterized by irregular fabric even though they are state-owned. Fig 3

- Areas established on agricultural lands, 
and are clearly shown in the regular division of urban fabric, which takes the form of agricultural holdings. They arise from the informal subdivision of agricultural land owned by individuals. Fig 4

The research is concerned with informal and semi-regular planned and safe areas. This, therefore, include communities built on State land or encroachments on agricultural land. This is the nearest model of a community system that provides suitable housing components at the urban, social and economic levels. It is the foundation that can be developed by the least possible means, and we can reach the urban output governed by the requirements of formal construction and customary rules that are respected by all. (H. A. A. 2007)

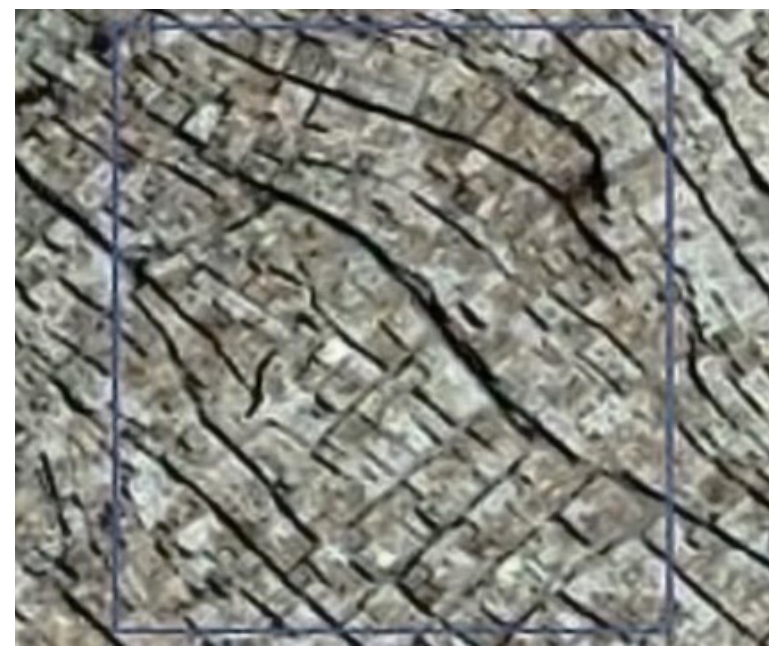

Figure 3. Irregular urban fabric. (Cairo Governorate 2008).

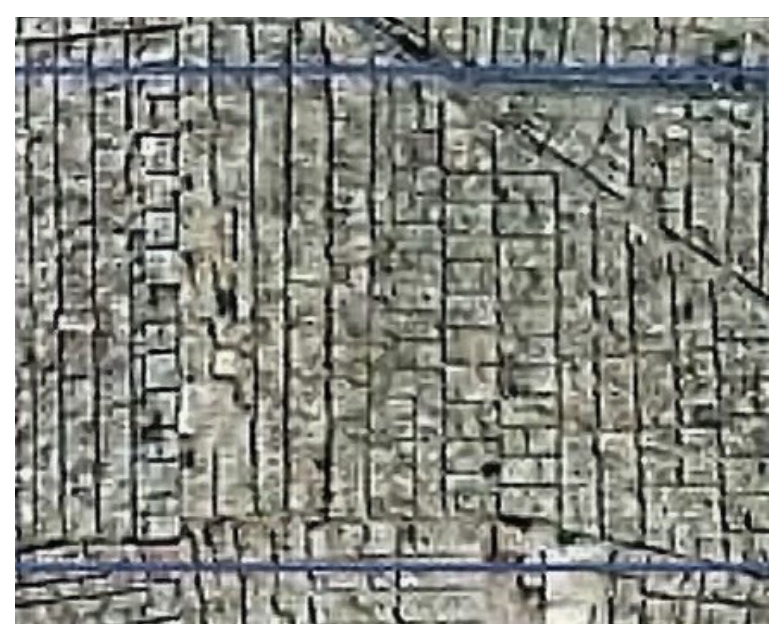

Figure 4. Regular urban fabric. (Cairo Governorate 2008).

\subsubsection{Informal settlements common features}

Most informal settlements' societies rely on attempts to provide private housing for individuals by obtaining a plot of land, participating in a part of a residential building or by contributing to cooperative societies, all of which are self-efforts without State supervision. The problem is that these attempts are not carried out in a legislative framework, but in accordance with informal transactions to divide the land that violate the building regulations, whether they belong to the state or are agricultural land.

The road network in most informal societies is characterized by varying degrees of width. They are wide on the boundaries of homogenous areas as key axes of movement, while the inner streets are too narrow. Fig. 5

The height of the buildings varies depending on the financial capacity of the owner. It also depends on proximity to the shopping areas and location of the plot on a main road or secondary road and ranges from two to 12 floors, but the majority consists of five floors, and all buildings are of

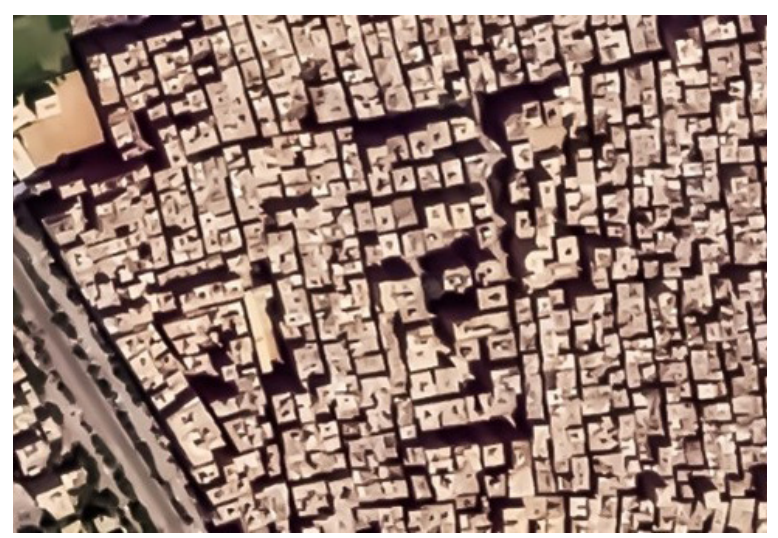

Figure 5. Main roads \& inner roads (GIZ 2011).

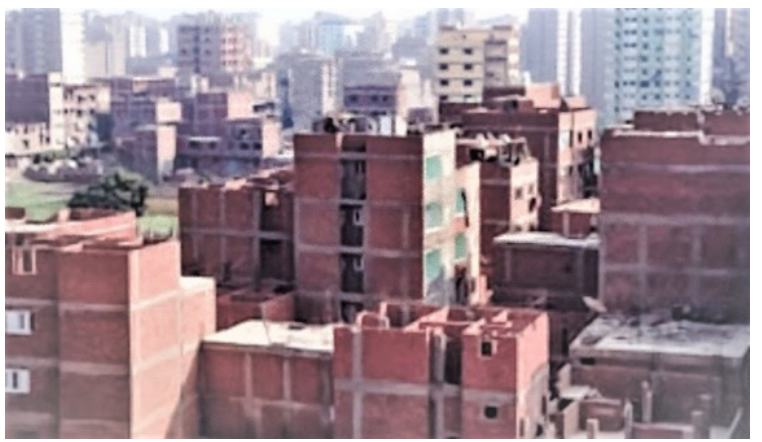

Figure 6. Buildings heights. (GIZ 2011). 
reinforced concrete. However, they are not subject to construction calculations or engineering supervision to check if they can bear all these heights. Fig. 6

In a study on informal settlements in the city of Assiut, it was found that the average area of the land is $75 \mathrm{~m} 2,90 \mathrm{~m} 2$, and in some cases may reach about $135 \mathrm{~m} 2$. These areas correspond to many informal settlements, in addition to some formal state authorized projects, such as "building your home", where construction occupies 63 $\mathrm{m} 2$ of land area of $150 \mathrm{~m} 2$. This means that the average size of the building, also the width of the plots of land within 8 meters are somewhat similar to the state of the subdivision of plot established in the informal settlements (I. H. A. 2002)

\subsection{Identification of Building Regulations - Re- lated to the Subject of the Research}

With the start of the organization of urban fabric in Egypt, the authorities resorted to a set of regulations, mostly derived from European regulations. This produced a semi-European urban fabric, so that cities lost many of their characteristics that should stem from customs, traditions, and determinants of the surrounding environment and the needs of different segments of society.

The first regulations governing the construction work in Egypt were issued to 1878 under the name of "Regulatory Authority Requirements". It provided for the organization of the road, the control of the protrusions areas and the laying of lines of regulation.

It should be noted that the Egyptian legislator quoted the maximum for the building height to be equal to one and a half times the width of the road from the building regulations in the downtown area of Paris, which was incorporated into the first building law in Egypt in 1942.

The Uniform Building Law No.119 for the year 2008 provides a set of general requirements. That achieves the minimum limits of healthy urban environment for its inhabitants. The details of minimum limits in the building regulations related to the subject matter of the research, are shown in table 1 and table 2 (Ministry of Housing 2008).
Table 2. Building law - minimum spaces dimensions.

\begin{tabular}{|c|c|c|c|}
\hline $\begin{array}{l}\text { Buildings } \\
\text { legislations }\end{array}$ & $\begin{array}{l}\text { Space } \\
\text { Type }\end{array}$ & $\begin{array}{l}\text { Minimum } \\
\text { dimensions }\end{array}$ & $\begin{array}{l}\text { Minimum } \\
\text { area }\end{array}$ \\
\hline Street width & \multicolumn{3}{|c|}{ At least 8 meters } \\
\hline \multirow{3}{*}{$\begin{array}{l}\text { Min. area of } \\
\text { inner rooms }\end{array}$} & Bedroom & $2.70 \mathrm{~m}$ & $10.0 \mathrm{~m}^{2}$ \\
\hline & Kitchen & $1.50 \mathrm{~m}$ & $3.0 \mathrm{~m}^{2}$ \\
\hline & Bathroom & $1.20 \mathrm{~m}$ & $2.0 \mathrm{~m}^{2}$ \\
\hline Net height & $\begin{array}{l}\text { flooring } \\
\text { to } \\
\text { ceiling }\end{array}$ & $2.70 \mathrm{~m}$ & -- \\
\hline $\begin{array}{l}\text { Maximum } \\
\text { building } \\
\text { height }\end{array}$ & Building & \multicolumn{2}{|c|}{$\begin{array}{l}\text { The building height is one and a } \\
\text { half times the width of the street } \\
\text { and does not exceed } 36 \mathrm{~m}\end{array}$} \\
\hline Staircase & Stair & \multicolumn{2}{|c|}{$\begin{array}{l}\text { The stair flight width is not less } \\
\text { than } 1.10 \mathrm{~m} \text { if units is not more } \\
\text { than } 4 \text { units }\end{array}$} \\
\hline \multirow{3}{*}{$\begin{array}{l}\text { Allowable } \\
\text { protrusion }\end{array}$} & Balcony & \multicolumn{2}{|c|}{$\begin{array}{l}\text { Max } 10 \% \text { of street width not } \\
\text { exceeding } 1.25 \mathrm{~m}\end{array}$} \\
\hline & $\begin{array}{l}\text { Low } \\
\text { window }\end{array}$ & \multicolumn{2}{|c|}{$\begin{array}{l}\text { Max } 5 \% \text { of street width not } \\
\text { exceeding } 1.25 \mathrm{~m}\end{array}$} \\
\hline & \multicolumn{3}{|c|}{$\begin{array}{l}\text { Low windows length does not exceed half the } \\
\text { length of the facade - leave } 1.5 \mathrm{~m} \text { from the } \\
\text { neighbour's border without protruding }\end{array}$} \\
\hline
\end{tabular}

Source: (Ministry of Housing 2008).

Table 2. Building law-minimum requirements for natural lightning and ventilation .

\begin{tabular}{llll}
\hline $\begin{array}{l}\text { The courts } \\
\text { to be lit } \\
\text { and } \\
\text { ventilated }\end{array}$ & Court type & $\begin{array}{l}\text { Minimum } \\
\text { width of the } \\
\text { court }\end{array}$ & $\begin{array}{l}\text { Minimum area } \\
\text { of the court }\end{array}$ \\
\hline $\begin{array}{l}\text { Residential } \\
\text { Courts }\end{array}$ & Internal & $\begin{array}{l}\text { Quarter of the } \\
\text { height or }\end{array}$ & $\begin{array}{l}\text { Square of quarter } \\
\text { height }\end{array}$ \\
& $\begin{array}{l}3.0 \mathrm{~m} \\
\text { whichever is } \\
\text { larger }\end{array}$ & \\
\hline $\begin{array}{l}\text { Service } \\
\text { Courts }\end{array}$ & Internal & $2.5 \mathrm{~m}$ & $\begin{array}{l}7.5 \mathrm{~m} 2 \text { - If } \\
\text { height is less } \\
\text { than } 10 \mathrm{~m}, \text { and } \\
\text { increase the area } \\
\text { by } 2.5 \mathrm{~m} 2 \text { for } \\
\text { each } 10 \mathrm{~m}\end{array}$ \\
\hline
\end{tabular}

Source: (Ministry of Housing 2008).

\section{Documenting The Current Situation Using Dar El-Salaam as a Sample}

There was evident lack of tracking of rapid growth areas in the last five decades or development of strategic plans to contain this increase in some areas and to keep pace with the increasing demand for construction. Plots of land were not provided in an appropriate place within the city cordon. This resulted in the people acting in an unplanned manner 


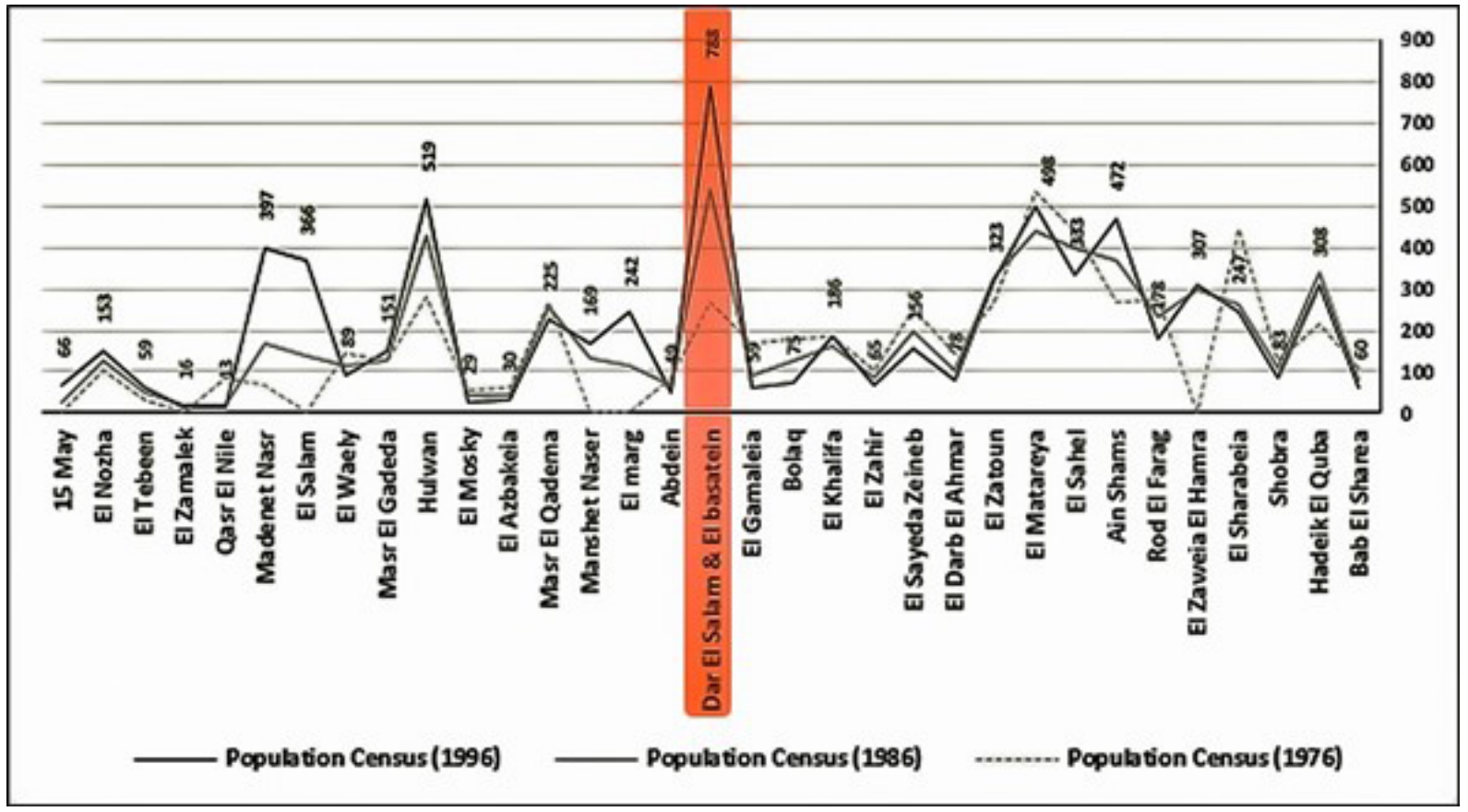

Figure 7. Rate of population growth in Cairo. (Central Agency for Public Mobilization and Statistics 1976, 1986, 1996).

and encroaching on agricultural lands by building on it, without taking into account the construction requirements, especially due to the lack of state supervision. Many informal settlements were built in this way. The following table shows the rapid population growth of areas that later formed the largest informal settlements in Cairo, of which we will address the most grown, Dar El Salaam area. Fig. 7

\subsection{The Scope of the Study}

Greater Cairo region is considered one of the highest densely populated ones in Egypt; this includes three governorates (Cairo, Giza and Qalioubia). It is also characterized by the rapid growth of informal settlements, which accounted for $40 \%$ of all informal settlements in Egypt, as well as the diversity of urban fabric accumulated over decades. This makes it a model worthy of study.

The Dar El Salam region has a unique and distinct location as a part of Cairo as it is located on the most important traffic axes in Cairo, which are the metro linking the south of Cairo with its north and the Nile Corniche (road along the Nile) leading to regional roads linking Cairo with all the governorates of the Republic, as it is located near the center of the country, which includes all ministries, administrative and commercial services, and transportation stations of all kinds for all governorates of the Republic. In addition, it is located near the Helwan suburb, which contains many labor-intensive factories, so the Dar El-Salam site was the closest area to housing workers and those with low or limited incomes. Fig. 8, Fig. 9

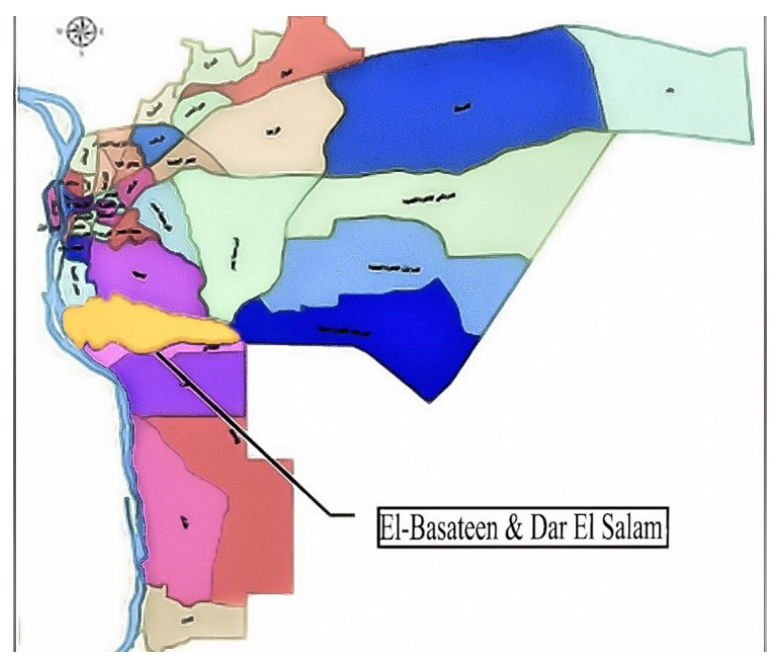

Figure 8. Administrative division of Cairo. (The online portal Cairo Governorate n.d.). 


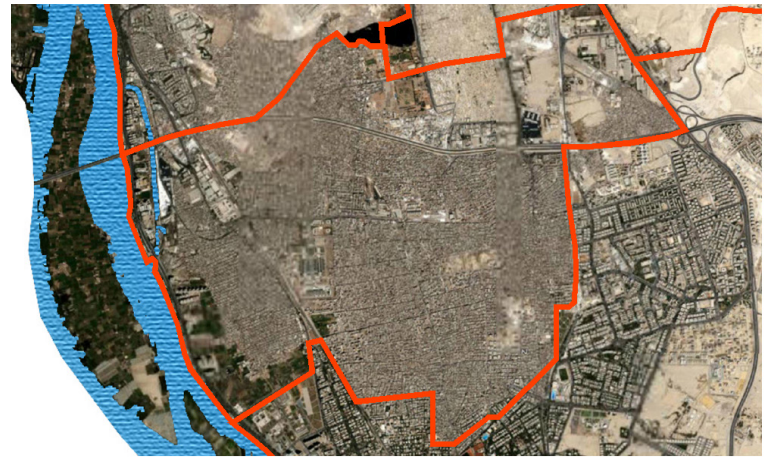

Figure 9. Urban cluster-Dar EI Salam. (Google Earth n.d.).

The Dar Al Salaam region, like other informal settlements, grew gradually according to the increase in the demand for construction, and thus there was no clear vision for the general planning of the area and the allocation of appropriate main and subsidiary traffic streets or services whether commercial or educational, or even adequate infrastructure and other services sufficient for the population density.

Given the neglect of the local authorities to allocate small plots of land near residential attractions (where there are opportunities for industrial and service work ... etc.), these marginalized groups were forced to search for illegal solutions to provide adequate shelter, regardless of violations of building requirements.

These factors combined made Dar El-Salam a strong point of attraction for those looking for housing at the lowest costs, near work areas and on the main movement axes. Figs.10, Figs.11

The study of Dar El Salaam, is the closest to the study of systems governing buildings. Therefore, it is possible to examine the possibility of avoiding the establishment of similar areas from

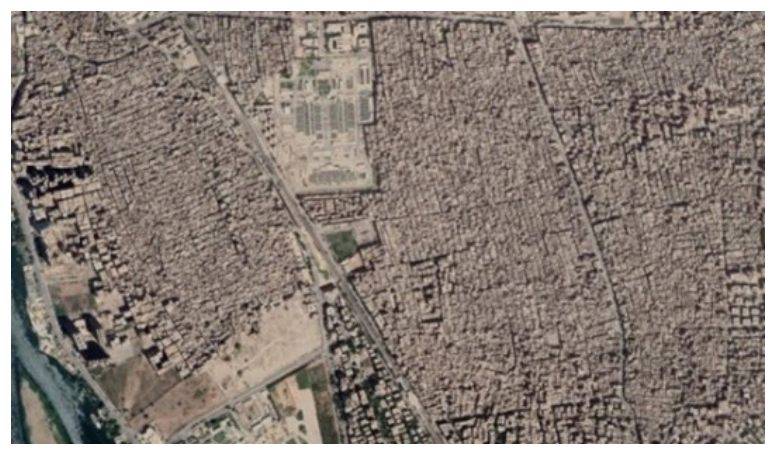

Figure 10. Dar El-Salam areas (Google Earth n.d.).

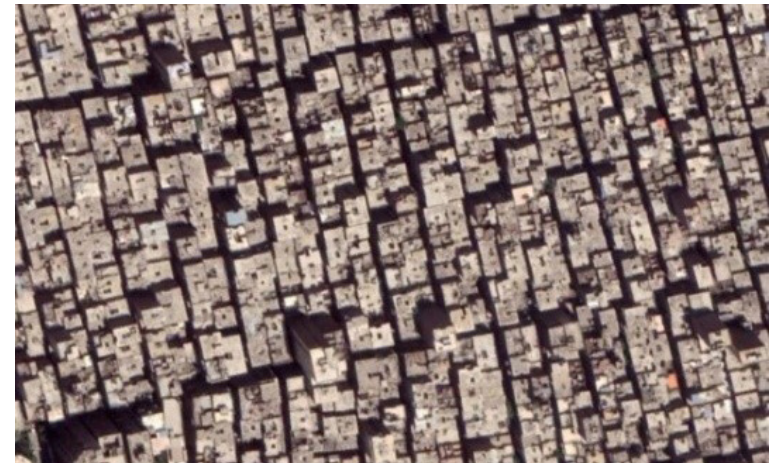

Figure 11. Semi-regular urban fabric. (Google Earth n.d.).

the outset informally, if flexibility was applied in the application of building requirements, without prejudice to elements that provide an appropriate urban environment. Therefore, the city of Dar Al Salaam is a good model for study and analysis, where measures can be drawn that can be activated to provide opportunities for these groups to obtain adequate shelter, and thus reducing the need for them resort to violating building laws to suit their needs.

\subsection{Documenting the Study Scope - Within the Terms of Building Requirements}

The mentioned area was formed as a result of the irregular and gradual construction on agricultural land. However, it is characterized by semi-ordered planning due to construction on the boundaries of agricultural holdings. The main characteristics of the area and the most important irregularities of building requirements can be summarized as follows:

- The streets around the study area are within limits of $16-18 \mathrm{~m}$ and the secondary streets are within limits of $8-12 \mathrm{~m}$. The inner streets are narrow width streets between $4-6 \mathrm{~m}$. Fig. 12

- The height of buildings is more than one and half times the street. This is contrary to the building requirements.

- Low windows were built within most of the building facades, while the building requirements stipulated that they should not exceed half the length of the facade.

- The depth of the protrusions is equal. While the requirements stipulate that the protrusion of the low windows is $5 \%$ of the street width, and $10 \%$ for the balconies with a maximum of 1.25 m. Fig. 13 


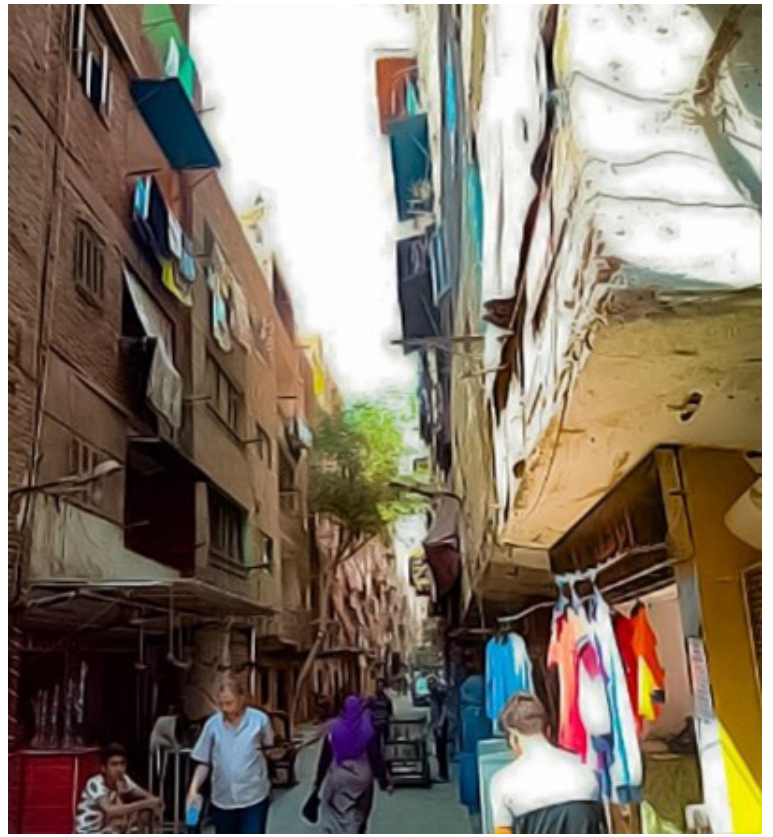

Figure 12. Narrow width streets.

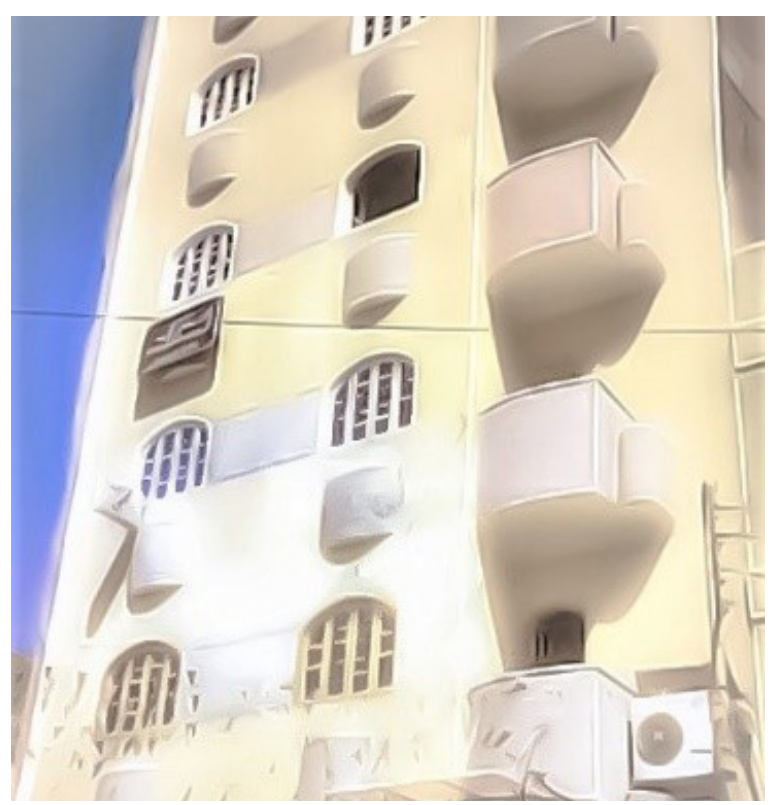

Figure 13. Balconies \& Low window ratio.

- The dimensions of Inner courts are smaller than the minimum requirements of the law; also they share service and residential areas. Fig. 14

- The stairs have no natural ventilation and the width of the stair flight is less than $1.10 \mathrm{~m}$ for four units or less.

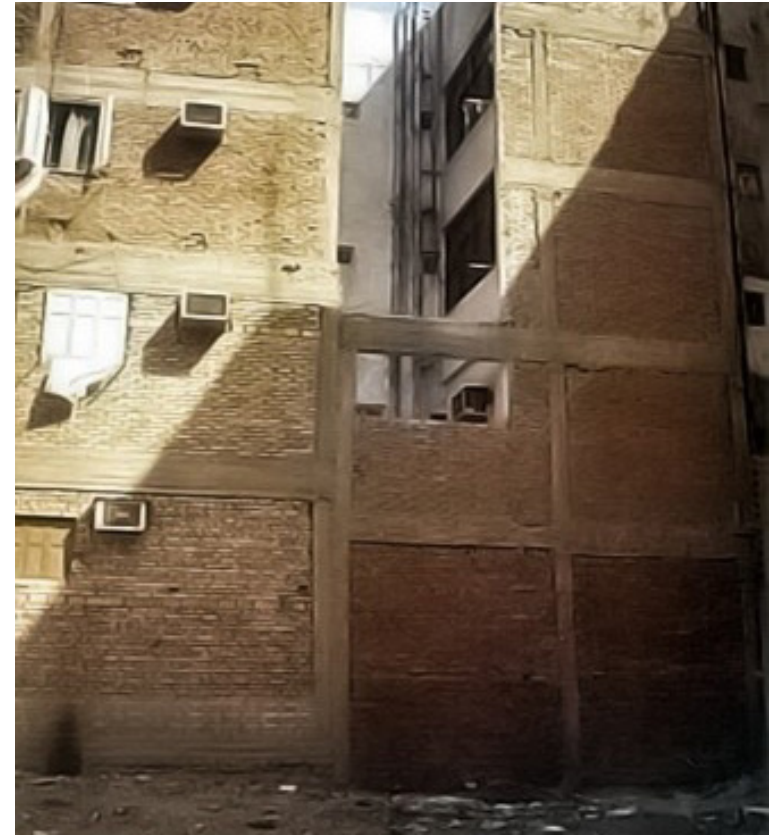

Figure 14. . Inner courts. (Author 2020).

- Residential inner Rooms, in general, are in the minimum limits mentioned in the executive regulations of the Unified Building Law No. 119 of 2008. (Ministry of Housing 2008).

The study sample is characterized by a semi-regular urban fabric, so the division of the land is repeated with a module $8.0 \mathrm{~m}$ and its multiples, so we can choose any of them such as "Hamed Seleem" street as a sample for study, Fig. 7. This street runs through 23 buildings, with 4.7 floors as average height. The residential units are distributed on each floor as follows: $34.8 \%$ of the buildings with two units / floor and $65.2 \%$ with units / floor.

The results of the field study (Author 2020) can be summarized in table 3 and table 4 . It shows that the results of the field study of this research correspond to both the field study of the informal settlements in the city of Alexandria in the research, Suleiman M., "Housing in Alexandria" (M. S. A., 1992), and the field study of the informal settlements in the city of Assiut in the research, Ibrahim $\mathrm{H}$. Ahmed A. A. \& Suleiman M. A., "The requirements of the areas and their effect on improving the characteristics of the urban environment". (I. H. A. 2002). 
Table 3. shows a comparison between the average area of residential units' elements in informal area within range of case study, and legislative rates, thus, most informal settlements have the same general features.

\begin{tabular}{llll}
\hline Comparative elements & Minimum building legislation & informal residential regions & Commitment \\
\hline Street width & At least 8 meters & From 4 to 6 meters & violated \\
\hline Min. area of inner rooms & Minimum area is $10.0 \mathrm{~m} 2$ & Avg. area is $11.35 \mathrm{~m} 2$ & achieved \\
\hline Net height & At least $2.70 \mathrm{~m}$ & At least $2.80 \mathrm{~m}$ & achieved \\
\hline building height & $\begin{array}{l}\text { Height is one and half times the street width } \\
\text { \&does not exceed } 36 \mathrm{~m}\end{array}$ & The height is twice or more the street width & violated \\
\hline Staircase & width of the stair flight is not less than $1.10 \mathrm{~m}$ & width of the stair flight is less than $1.10 \mathrm{~m}$ & violated \\
\hline $\begin{array}{l}\text { Max. protrusions for } \\
\text { Balcony and Low } \\
\text { window }\end{array}$ & $\begin{array}{l}\text { Max } 10 \% \text { for Balcony and 5\% for Low } \\
\text { window of street width }\end{array}$ & $\begin{array}{l}\text { low windows depth of } 1.25 \mathrm{~m} \text { and its length } \\
\text { is more than half the facade }\end{array}$ & violated \\
\hline
\end{tabular}

Source: (Author 2020).

Table 4. shows a comparison between the average of courts in informal area within range of case study, and legislative rates.

\begin{tabular}{|c|c|c|c|c|c|}
\hline \multirow{2}{*}{$\begin{array}{l}\text { The courts } \\
\text { to be lit and } \\
\text { ventilated }\end{array}$} & \multicolumn{2}{|c|}{ Minimum building legislation } & \multicolumn{2}{|c|}{ informal residential regions } & \multirow[b]{2}{*}{ Commitment } \\
\hline & $\begin{array}{l}\text { Minimum width of the } \\
\text { court }\end{array}$ & Minimum area of the court & $\begin{array}{l}\text { Average width } \\
\text { of the court }\end{array}$ & $\begin{array}{l}\text { Average area of the } \\
\text { court }\end{array}$ & \\
\hline $\begin{array}{l}\text { Residential } \\
\text { courts }\end{array}$ & $\begin{array}{l}\text { Quarter of the height or } \\
3.0 \mathrm{~m} \text { whichever is larger }\end{array}$ & Square of quarter height & $\begin{array}{l}\text { Avg. width is } \\
1.60 \mathrm{~m}\end{array}$ & Avg. area is $2.20 \mathrm{~m} 2$ & violated \\
\hline $\begin{array}{l}\text { Service } \\
\text { courts }\end{array}$ & $2.5 \mathrm{~m}$ & $\begin{array}{l}7.5 \mathrm{~m} 2 \text { - If height is less than } \\
10 \mathrm{~m} \text {, and increase the area } \\
\text { by } 2.5 \mathrm{~m} 2 \text { for each } 10 \mathrm{~m}\end{array}$ & $\begin{array}{l}\text { Avg. width is } \\
1.60 \mathrm{~m}\end{array}$ & Avg. area is $2.20 \mathrm{~m} 2$ & violated \\
\hline
\end{tabular}

Source: (Author 2020).

\section{The Experience of Social Housing - New Cairo}

The State has offered land plots in the new cities under the name of family housing. The idea is based on two adjacent buildings sharing a common service facility, while documenting the area and place of the court in the contracts, known as the right of easement, to reduce the loss in the built area in the small lands, instead of allocating a separate court for each one. Fig. 15

The right of the easement was mentioned in the Egyptian Building Law, "The owners of the neighboring real estate may agree to establish common inner courts where the conditions stipulated in the regulations are met" (Ministry of Justice 1949).

Article (1015) of the Egyptian civil code defines "easement as a right limiting the benefit of a property to the benefit of another property owned by another person ...". (New Urban Communities authority 2010).
The right of easement is the specific commissioning for the use and benefit of a property owned by another owner. Thus, the right of the easement is an important basis to be followed in low-income areas as a tool to maximize the utilization of small land plots.

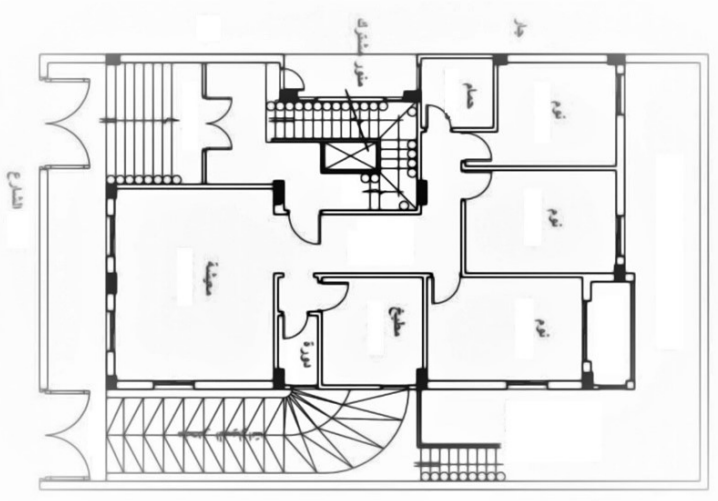

Figure 15. Family housing. 


\section{Proposed Amendments to Avoid the Formation of More Informal settlements}

From the documenting of the study scope, it can be concluded that the most visible irregularities in the informal settlements were the areas of services and the residential courts being small, width of the streets being small, the height of the buildings being beyond the permissible limits and the increase of low windows beyond the permissible limits.

From this point of view, an example floor plan can be given to explain the ability of demonstrating the use of easement in courts and their impact on compliance with regulations by individuals. It can be developed with deep researches for actual needs.

\subsection{At the Level of Housing Units and Activat- ing the Easement Law}

In the sample presented, for the current design of one unit per floor, Fig. 16, it turns out that the flats' courts areas $(2.5 \mathrm{~m} 2,3.75 \mathrm{~m} 2)$ are very small, so it does not achieve the required minimum area and the courts width does not exceed $1.5 \mathrm{~m}$.

This causes health problems due to poor ventilation and lack of natural lighting, as well as loss of privacy, as a direct result of the lack of engineering supervision of the design. (Utilities and Urban Communities 2017), making it a model worthy of study.

In order to avoid increasing the area of courts for small plot land, the study proposes to take advantage of the shared courts according to the right of easement law, which can be illustrated in the proposed model example, which presents dwelling unit Fig. 17. with consideration that the easement courts shared with the neighbor, whether service or residential are integrated to achieve the permissible limits, also the width is $(2.5 \mathrm{~m}$ for service $\& 3.0 \mathrm{~m}$ for residential) within the permissible limits.

The comparison between the current and proposed situation is shown in following: Fig. 18

- Increase in the area utilized on the ground floor in proposed model than current situation.

- The exploitation of surfaces in the typical floors between the current model and the proposed model is convergent.

- The great difference is evident between the traditional system of applying building requirements on each plot of land and the exploitation of shared courts with easement.
- The proposed model appropriates light and ventilation rates achieved by providing service and residential courts conforming to the building regulations requirements.

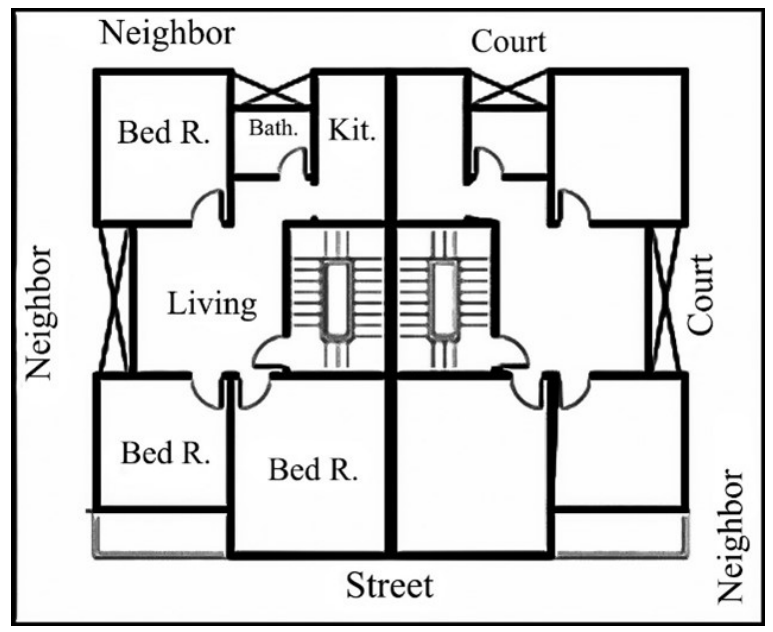

Figure 16. Current design with one unit (Author 2020).

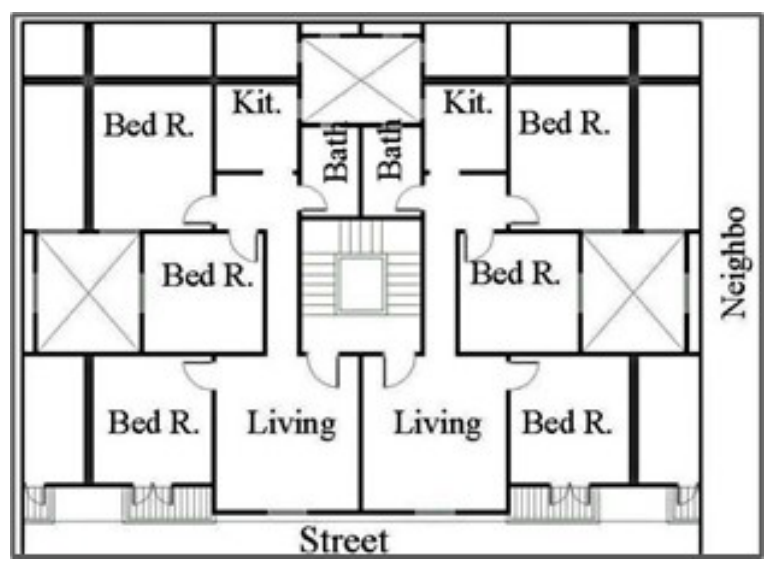

Figure 17. A proposed model with two units (Author 2020).

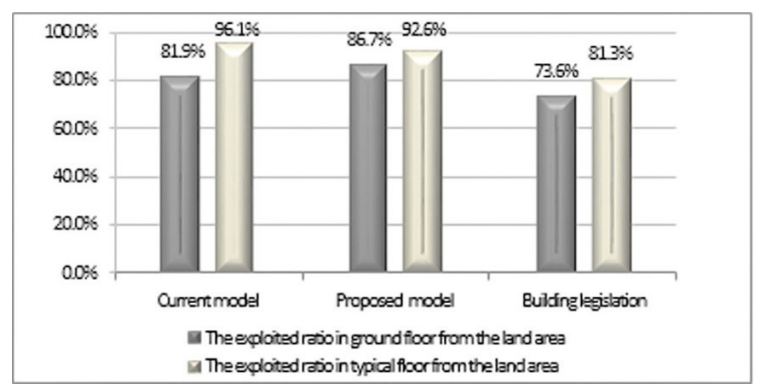

Figure 18. The comparison between the current and the proposed situation. (Author 2020). 


\subsection{At the Level of Urban Fabric and Building Density}

The urban fabric in the current situation is very compact. The number of housing units is 175 units per feddan (acre) with a net population density of 875 individuals per feddan, this is a very high density (Calculated from maps). Therefore, to reduce it in planning future areas that the State must provide in the scope of urban frame the street width must be at least $8 \mathrm{~m}$, where the number of housing units will be 128 units (Calculated from maps). If it's recommended to allocate green areas to alleviate this problem, the population density will be within 500 individuals/ feddan in an adequate range.

\subsection{The Height of Buildings and protrusion on the Facades as a ratio of street width}

There is no reason for the difference in the protrusions of balconies or low windows, or to determine that the low windows should not exceed half the façade; these are requirements borrowed from the French law in 1942 which did not change according to the cultural and environmental conditions. It is noted that the minimum net height of the floor is $2.7 \mathrm{~m}$, if we add the thickness of the ceiling slab and the flooring, then the height of the building will be multiples of

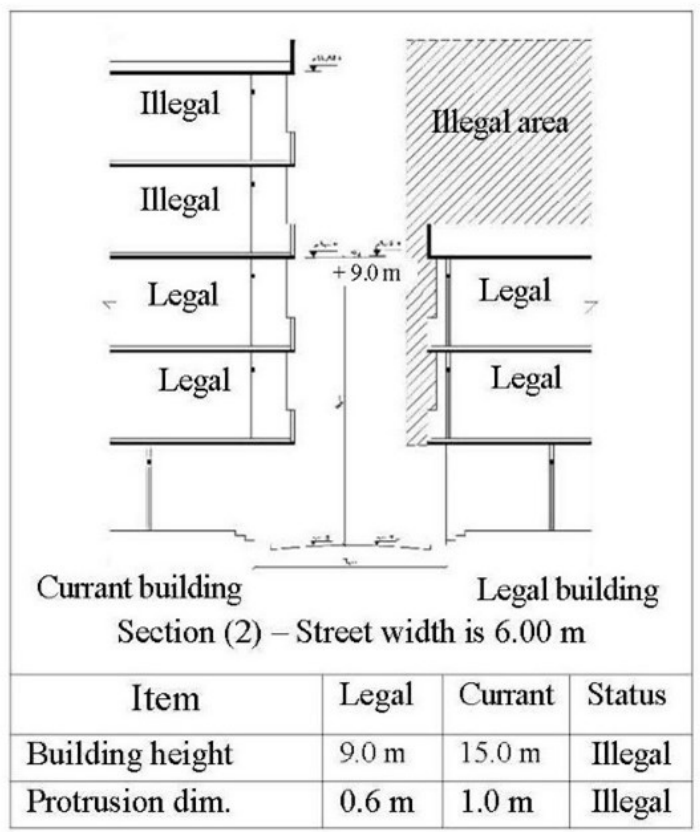

Figure 19. Section analysis, Street width is $6.0 \mathrm{~m}$.
$3.0 \mathrm{~m}$.

The height of the building with the streets width $(7.0 \mathrm{~m}, 9.0 \mathrm{~m})$ is not linked with the repetition of the height of the floors. In this case the height of the building will be $(10.5 \mathrm{~m}, 13.5 \mathrm{~m})$, as they are not with the repetition of the height of the floors $3.00 \mathrm{~m}$. So there is a wasted area as shown in Fig. 21

If the height of the buildings corresponds to the streets with dimensions $(6.0 \mathrm{~m}, 8.0 \mathrm{~m}, 10 \mathrm{~m})$, then in this case the height of the building will be $(9.0 \mathrm{~m}, 12.0 \mathrm{~m}$ and $12.5 \mathrm{~m})$, shown in figures 19 , 20 .and 22 , with repeatability of the floors height.

In this case the width of the street is 5.0 or $6.0 \mathrm{~m}$ and with $1 \mathrm{~m}$ depth low windows protrusion, then the remaining only $4.0 \mathrm{~m}$ between the buildings at typical floor. This is not suitable for privacy or car traffic. Therefore, if the width of the street is $8.0 \mathrm{~m}$ with pavement of $1.0 \mathrm{~m}$, the remaining street width will be $6.0 \mathrm{~m}$. and this suitable for traffic passage according to the urban regulations.

This is as close as possible to achieving the economic benefit of the building by providing building height for the largest possible number of housing units without violating the requirements of buildings.

The figures below show a comparison between the cross sections in street width and buildings height in informal settlements and legislative rates: (Author 2020).

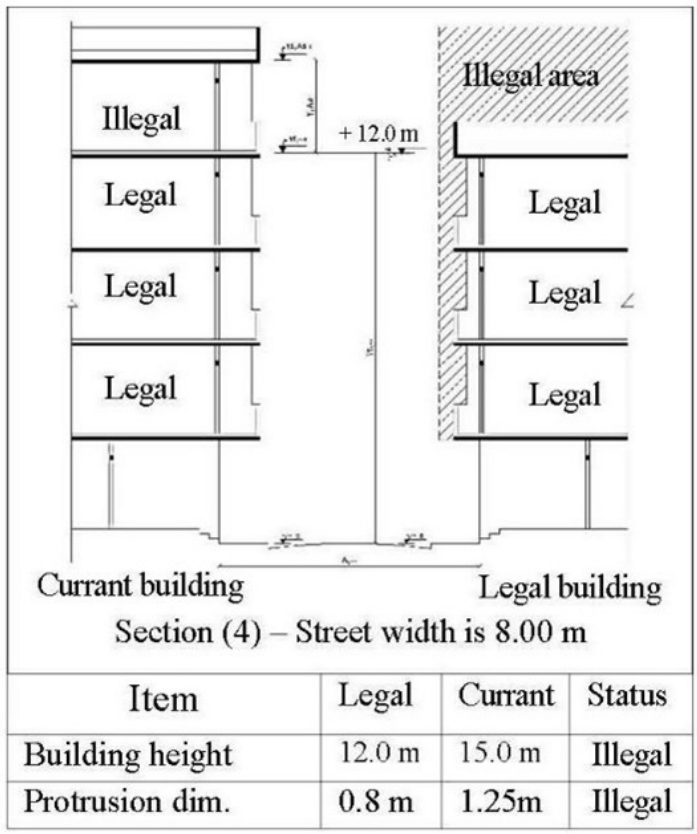

Figure 20. Section analysis, Street width is $8.0 \mathrm{~m}$. 


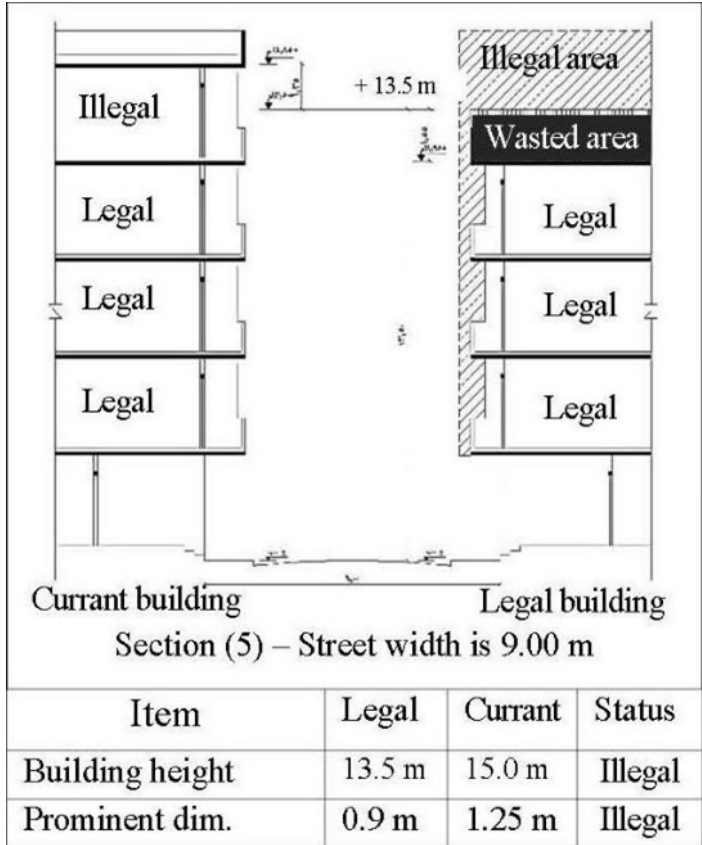

Figure 21. Section analysis, Street width is $9.0 \mathrm{~m}$.

\subsection{General features of violations of building regulations in informal settlements}

It is clear from the research that most of the violations of building regulations can be summarized in the following:

- Inner streets width ranges from 4 to 6 meters. Therefore, it does not meet the minimum width stipulated in the detailed plans manual issued by the Urban Planning Commission,

- the inner residential spaces achieve the limits allowed in the building requirements

- Height of buildings is more than one and half times of the street width.

- Dimensions of Inner courts are smaller thanthe minimum requirements of the law; also service courts and residential courts are shared with the same spaces.

- Violation of balcony and low windows, either in the ratio of protrusions of the width of the street or increase in the low windows ratio to more than of half of the length of the facade.

- The plot of land area in the informal settlements is less than $120.0 \mathrm{~m} 2$ and has one facade within the range of $8.0 \mathrm{~m}$. This is not equivalent to the minimum area

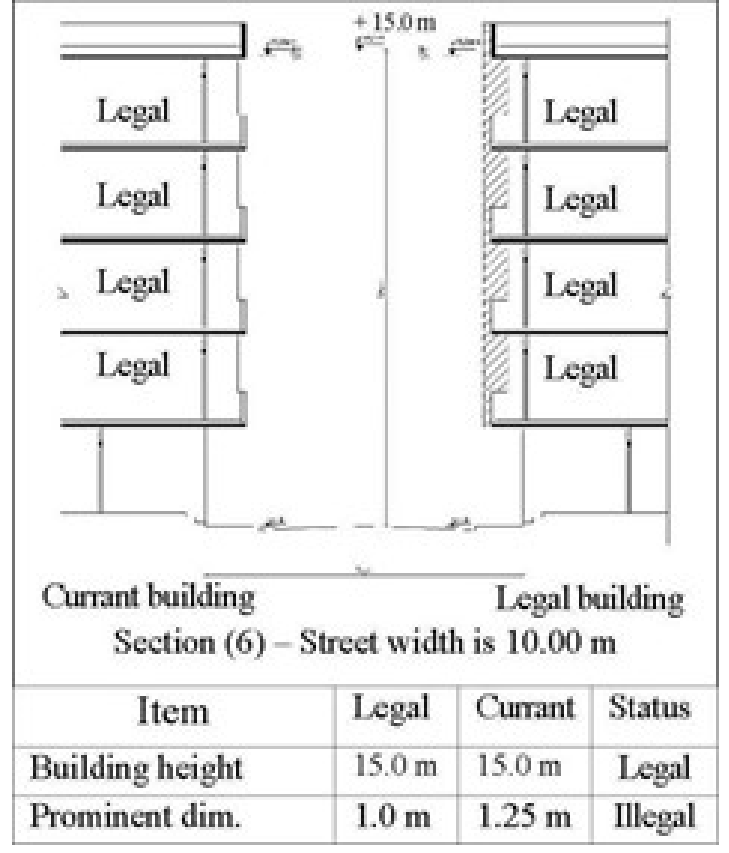

Figure 22. Section analysis, Street width is $10.0 \mathrm{~m}$.

stipulated in the detailed plans manual issued by the Urban Planning Commission, 2017, which states that the area of the plot of land allocated for housing isn't less than $120.0 \mathrm{~m} 2$ while the facade on the street is at least $10.0 \mathrm{~m}$.

- With the application of building regulations requirements, the service area of the building will be approximately 33.0 $\mathrm{m} 2(10.0 \mathrm{~m} 2$ service court, $9.0 \mathrm{~m} 2$ residential court, $14.0 \mathrm{~m} 2$ for stairs). This leads to the loss of about $30 \%$ of the area of the plot.

- There is no relation between the height of the floor (about $3 \mathrm{~m}$ ) and the total height of the building. For example, if the width of the street is $5 \mathrm{~m}$, the height of the building allowed is $7.5 \mathrm{~m}$. So the owner of the plot loses $1.5 \mathrm{~m}$ of the building height, because it is not sufficient to build an additional floor, forcing him to violate the building regulations.

- The right of easement It is not utilized to benefit from the shared courts to reduce losses in areas is not used when applying the building regulations for residential and service courts. 


\section{Conclusion}

It is evident from the study that the Dar Al Salaam region as a model has buildings in good structural condition, and its urban fabric is semi-regular. Also building violations (evidenced by the field study) are mostly in street widths, building heights, and courts areas. So, building regulations that take into account the limited economic potential of these groups is needed.

Therefore, the study recommends monitoring areas of rapid growth and providing small plots of land in the urban space for these areas near work areas and on major movement axes away from agricultural lands.

There is a need to revise the minimum plot area of land allowed for construction within the urban zone of cities, as long as it is sufficient to build inner residential spaces compliant with the building regulations. A large proportion of land in informal settlements have areas less than 120.0 $\mathrm{m} 2$, mainly between $80.0-100.0 \mathrm{~m} 2$ (equivalent to half a carat which is the most common of plots), because of the need to build in a small space to reduce the cost of the building. As this is the maximum potential of low-income groups, then it is necessary for the State to provide plots within 90.0-100 $\mathrm{m} 2$, and to take into account the needs of this category and their right to find shelter at the lowest possible cost without violating the building regulations.

The study recommends the addition of a mandatory requirement for building regulations to share in courts under the right of easement, between plots of land less than $120.0 \mathrm{~m} 2$ and does not grant a building permit otherwise. In this case, the area of the service areas is about 22.25 $\mathrm{m} 2(3.0 \mathrm{~m} 2$ service courts, $5.2 \mathrm{~m} 2$ residential court and $14.0 \mathrm{~m} 2$ for stair). This leads to a reduction of losses of about $18 \%$ of the small land area $(90.0$ $\mathrm{m} 2)$. Thus, it is an important incentive for low-income groups to comply with building regulations.

It is appropriate that the width of the street in the urban Planning provided by the state within the urban zone of the city be not less than $8.0 \mathrm{~m}$; in this case, the maximum permissible height is $12.0 \mathrm{~m}$, which is enough for four floors. This increases the efficiency of exploitation of the plot of land for the owner.

Since the first drafting of the law was in 1942 and upt o to date, the ratio of low window protrusions is still $5 \%$ and balconies are $10 \%$ of the width of the street, without deep studies. So there is no obvious reason not to unify the low protrusion of windows and balconies with the same $10 \%$ of the width of the street, as it is suitable to be a multiple of $0.25 \mathrm{~m}$, if the street width is about $8.0 \mathrm{~m}$ the protrusions will be $1.00 \mathrm{~m}$, a small compromise that can be reasonably accepted as a solution that suits both the owner and the legislator

To facilitate the possibility of complying with building requirements, it is better to suggest some design alternatives as guidelines that facilitates the implementation of the principle of participation in service and residential courts, and to achieve the requirements of the architectural environment appropriate for the building users, and can be developed later with in-depth research for the actual reality.

\section{References}

A., Hassan A. S. \& Eid M. A. \& Youssef M. "Towards objective criteria for identifying areas of low-income housing in Egypt." Housing Symposium 3. Riyadh: Supreme Commission for the Development of Riyadh City, (2007). 9.

A., Ibrahim H. Ahmed A. A. \& Suleiman M. "The requirements of the areas and their effect on improving the characteristics of the urban environment." Faculty of Engineering Benha, 2002: 15,16.

Author. "Field documentation of the study area." Cairo: Author, (2020).

Cairo Governorate. Urban development and the challenges of Informal Areas. General Office, Cairo: Cairo Governorate, 2008.

Central Agency for Public Mobilization and Statistics. "Population for the years (1976, 1986, 1996)." Cairo, (1976, 1986, 1996).

ElBatrawy, Menha. Random urbanization. Cairo: Dar El Ein for Publishingtranslating: Galila El kadi (1987)"L'Urbanisation spontanee Au Caire"Fascicule de Rechercheres no 18-URBAMA/TOURS/O.R.S.T.OM,France, (2009).

GIZ, German Development Cooperation Office in Cairo \& Egyptian Ministry of Planning. Development of informal areas of participation. Cairo: urban participatory development program in Egypt, (2011), 56. 
Google Earth. Maps. n.d. https://earth.google.com/web/@0,0,0a,2225175 $.77375655 \mathrm{~d}, 35 \mathrm{y}, 0 \mathrm{~h}, 0 \mathrm{t}, 0 \mathrm{r},(2020)$.

I., Abdel Samie M. - Abdel Moneim. "Lessons Learned from Random Inclusion in Housing Facilitation Framework." Facilitated Housing Seminar. Riyadh: Supreme Council for the Development of Riyadh City, (2004). 15.

Information and Decision Support Center. Informal Areas in Egypt: facts and figures. Cairo: Ministers' Affairs, (No. 12793), (2014), 4.

M., Hafez N. The efficiency of informal areas in Egypt - activating the relationship between the user group and the construction product. Faculty of Engineering, Cairo University, Cairo: Cairo University, 2015, 56.

M., Suleiman A. Housing in Alexandria. Liver Pool: Liver Pool University press, ODA, (1992), 8.

Ministry of Housing. Unified Building Law No.119. Cairo: Ministry of Housing, (2008).

Ministry of Justice. "Egyptian Civil Law." Cairo: Ministry of Justice, (1949).

New Urban Communities authority. Social housing building models. Cairo: New urban communities, (2010).

Ragih, AboZeid. Egyptian Urbanization : Monitoring Development in Urbaniztion in Egyptian land in late twentieth century and predicting its future Routes in 2020. Vol. volume 2. Academic Library in Cairo, (2008).

Regina, K\&Marion,F. Cairo's Informal Areas betwwen Urban Challenges and Hidden Potentials,Facts.voices.vision. op.cit, (2009).

Sims, David. "The Challenge of slums: Global report on Human settelments-The case of Cairo, Egypt." Nairobi: UN-Habitat, (2003).

The online portal Cairo Governorate. Electronic gate. n.d. http://www.cairo.gov.eg/ en/pages/CairoInLines.aspx?CiLID=3.

Utilities and Urban Communities. Guide to the work of detailed plans. Cairo: Ministry of Housing, Utilities and Urban Communities, (2017). 


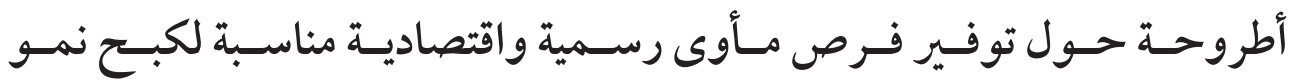 المناطـق العشــــئية}

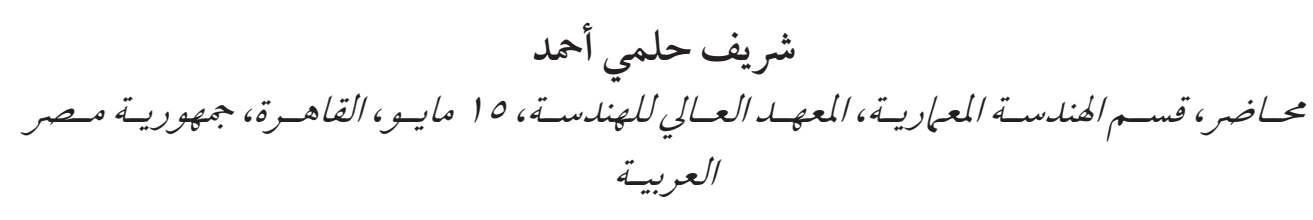
sh_100sh@yahoo.com

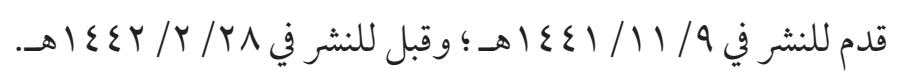

ملخص البحث. تعدُّ المناطق غير الرسمية (العشوائية) من أهم مشكلات التنمية الحضرية في القاهرة، حيث

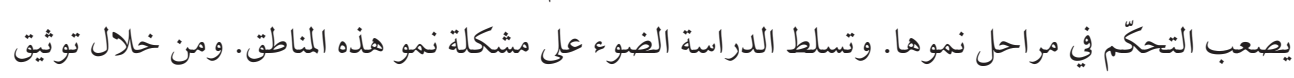
أهم مخالفات اشتراطات البناء، وبدراسة خصائص منطقة الدراسة؛ يمكن تطوير أطروحة لتحقيق التوازن بين احتياجات ذوي الدخل المنخفض في السكن، والحد الأدنى من المتطلبات البيئية العمر انية والصحية المناسبة.

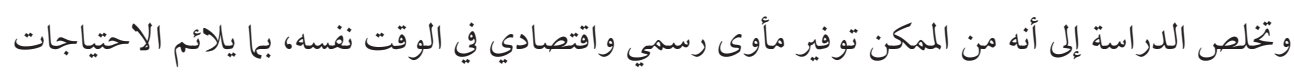

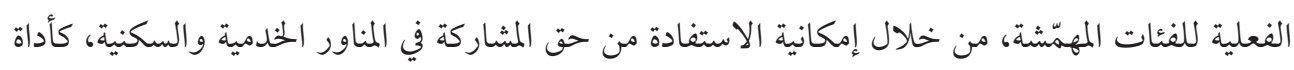

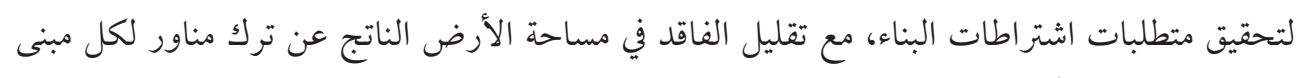

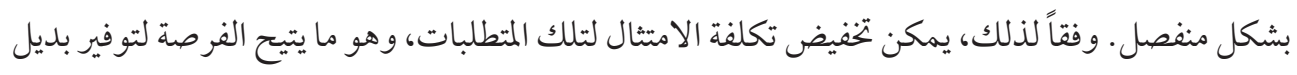
اقتصادي يتفق مع اشتراطات البناء داخل المناطق الحضرية الرسمية، ولن تكون هناك حاجة للبناء بالمخالفة لاشتراطات البناء. وبالتالي، يمكننا تحقيق الهدف من الدراسة في الحد من نمو المناطق غير الرسمية، وتقليل فرص تكوين المزيد منها.

الكلمات المفتاحية: مناطق غير رسمية، عشو ائيات، اشتراطات البناء، قانون حق الارتفاق، النسيج العمراني. 